\section{PENGARUH PENGGUNAAN KUNING TELUR DAN POLARASOL SS TERHADAP KEMULURAN KULIT KRAS KAMBING}

Oleh : Bambang Oetojo

\section{ABSTRACT}

The objective of this research is to know the influence of using egg yolk and Polarasol SS in fatliquoring process to the stretch of the goat crust leather. It was used 18 pieces of goat wet blue skin in this research. They were neutralized so as to the pH 6.0-6.5. A part of goat wet blue skins were fatliquored with egg yolk $5.0 \%, 7.5 \%$ and $10 \%$ successively. The other part was fatliquored using Polarasol SS by the same manner to that one of using egg yolk. The subsequence process were fixation, aging. sammying. drying, conditioning, sticking and taking. The goat crust leathers output were visual investigated for the appearance, sofness and smoothness. Whereas physical testing for the stretch of those ones. Practical meaning of this research is, fatliquoring process using egg yolk gives a cleaner grain surface and smoother goat crust leather than using Polarasol SS. Whereas Polarasol SS gives softer and higher stretch of goat crust leather than using egg yolk.

\section{INTISARI}

Tujuan penelitian adalah untuk mengetahui pengaruh kuning telur dan polarasol SS dalam proses peminyakan terhadap kamuiuran kulit kras kambing. Digunakan 18 lembar kulit krom basah kambing Kulit krom basah dinetralisasi sehingga pHnya 6,0-6,5. Sebagian kulit krom basah kambing diminyak dengan kuning telur berturut-turut 5,0\%, 7,5\% dan 10\%. Sebagian lagi diminyak menggunakan Polarasol SS dengan cara yang sama seperti pada waktu menggunakan kuning telur. Proses selanjutnya adalah fiksasi, pemeraman, pemerahan, pengeringan, pelembaban, perenggangan dan pementangan Kulit kras yang dihasilkan diamati mengenai penampilan, kelemasan dan kehalusan. Sedang uji fisis mengenai kemuluran kulit kras kambing. Arti praktis dari penelitian ini adalah, proses peminyakan menggunakan kuning telur menghasilkan kulit kras dengan permukaan bersih dan halus, dari pada menggunakan Polarasol SS. Sedang Polarasol SS menghasilkan kulit kras yang lebih lemas dan kemulurannya lebih tinggi dari pada apa bila kita menggunakan kuning telur.

\section{PENDAHULUAN}

Adapun tujuan utama proses penyamakan adalah untuk melindungi fiber kulit terhadap serangan bakteri atau mencegah kerusakan kulit karena faktor-faktor lain.

Pada proses pendahuluan, yaitu pembuangan bulu dan pengikisan protein, sebagian besar minyak alami di dalam kulit menjadi hilang (8). Oleh karena itu setelah kulit selesai disamak, apabila fiber kulit tidak dilapisi film suatu minyak, kulit menjadi kaku dan mengeras setelah mengering (1.5.8.9). Adanya minyak dengan jumlah relatip kecil dalam kulit jadi, apabila tersebar secara merata pada fiber, dapat mengurangi kekakuan dan kekerasan kulit jadi. Secara umum, kulit jadi menjadi lebih lemas dan regangnya lebih tinggi, apabila pada pelumasan menggunakan minyak lebih banyak (5).

Karena memegang peranan yang mendasar, penggunaan minyak dan lemak sering dikaitkan dengan perubahan sifat-sifat kulit jadi (5). Minyak dan lemak menyebabkan kulit jadi menjadi lemas, berisi, lembut, lentur dan menambah kekuatan serta kemuluran kulit tanpa retak (1.4.9). Demikian pula dapat menambah kemampuan mengambil serta menahan air dan menambah kehalusan rajah (5).

Pelumasan terhadap kulit samak dengan minyak secara layak adalah perlu, karena mengandung banyak manfaat bagi kulit samak tersebut (3). Namun harus dipertimbangkan mengenai syarat penggunaan minyak, sifat minyak yang digunakan dan jenis minyak yang digunakan. Jenis kulit jadi serta sifatnya akan menentukan jenis dan besarnya minyak yang digunakan untuk melumasi kulit samak (1.5.8). Cara pelumasan kuit samak dengan minyak sangat tergantung pada jenis kulit jadi yang akan dihasilkan (1.3). Pada umumnya cara pelumasan kulit dengan minyak menggunakan air sebagai perantara, dimana minyak dibawa masuk ke dalam kulit samak dengan perantara suatu pengemulsi (2). Emulsi dibuat dengan jalan melarutkan minyak mentah ke dalam air dengan pertolongan suatu pengemulsi, antara lain sabun, minyak sulfat dan bermacam-macam pengemulsi lainnya yang ada dipasar. Memasukkan minyak ke dalam kulit samak dengan cara mengemulsikan minyak di dalam air dinamakan peminyakan (4).

Jenis-jenis minyak yang digunakan dalam proses peminyakan, umumnya adalah trigliserida yang diperoleh dari tumbuh-tumbuhan, ikan laut dan hewan (4.8).

Secara kimiawi, kuning telur mengandung air : $48,7 \%$; protein : $16,6 \%$; lipida $32,6 \%$; karbohidrat : $1 \%$ dan mineral : $1 \%$ (2). Lipida kuning telur terdiri atas trigliserida : $65,5 \%$; phospholipida : $28,3 \%$ dan cholesterol : $5,2 \%$ (2.6). Phospholipida adalah sesuatu senyawa yang terdiri dari phosphor dan nitrogen. Lipida utama adalah ovolecithin yang membentuk kira-kira 8,6\% kuning telur padat (2).

Disamping merupakan emulsi yang khas, kuning telur mengandung protein yang memiliki pengaruh dalam stabilisasi. Kestabilan kuning telur disebabkan oleh lesithin protein, suatu kompleks yang terdiri atas lecithin dan protein. Dengan demikian kuning telur tidak hanya memiliki kemampuan untuk mengemulsikan larutan yang lain, tetapi juga merupakan stabilisator yang baik. Kuning telur mempunyai $\mathrm{pH} 6,0$ (2). Polarasol SS adalah hasil pengesteran yang tinggi dengan maksud agar meningkatkan kelemasan kulit dan baik untuk kulit kras yang putih.

Pada pembuatan kulit glase, besarnya minyak yang digunakan adalah sebesar $5,0 \%$ dan penggunaan air sekecil mungkin (5). 


\section{MATERI DAN METODA}

Materi

Dalam penelitian ini menggunakan kulit kambing krom basah (wet blue) sebanyak 18 lembar, kuning telur, polarasol SS, $\mathrm{NaHCO} 3$ dan $\mathrm{HCOOH}$.

Alat-alat yang digunakan dalam penelitian ini adalah drum penelitian, timbangan digital, kertas $\mathrm{pH}$ dan mesin uji kemuluran kulit.

\section{Metoda}

Kulit kambing krom basah sebanyak 18 lembar. Kulit kambing krom basah tersebut dalam keadaan asam ( $\mathrm{pH} 3,5-4,8)$. Berhubung proses selanjutnya harus dikerjakan dalam keadaan netral ( $\mathrm{pH} 6,0-6,5)$, maka kulit kambing krom basah harus dibuat dalam keadaan netral pula, yaitu dengan menggunakan $\mathrm{NaHCO} 3$. Proses netralisasi dikerjakan sesuai dengan metode yang biasa digunakan di Balai Besar Penelitian dan Pengembangan Industri Barang Kulit, Karet dan Plastik.

Setelah kulit kambing krom basah dalam keadaan netral, selanjutnya dikerjakan proses peminyakan. Sebagian kulit kambing krom basah diminyaki dengan kuning telur sebesar $5,0 \%, 7,5 \%$ dan $10,0 \%$. Sebagian yang lain diminyak dengan Polarasol SS sebesar $5,0 \%, 7,5 \%$ dan $10,0 \%$. Air yang digunakan dalam proses peminyakan sebesar $30 \%$. Langkah-langkah selanjutnya adalah fiksasi, pemeraman, pemerahan, pengeringan, pelembaban, peregangan dan pementangan.

Selanjutnya kulit kras kambing yang dihasilkan dalam penelitian, diuji secara indera mengenai penampilan, kerataan dan kelembutannya. Sedangkan uji secara fisis mengenai kemuluran kulit kras kambing. Data hasil uji kemuluran kulit kras kambing dianalisa secara statistik menggunakan SRD (7).

\section{HASIL DAN PEMBAHASAN}

Untuk mengetahui pengaruh penggunaan kuning telur dan Polarasol SS dalam proses peminyakan terhadap keadaan kulit kras kambing yang dihasilkan, maka dilakukan pengamatan secara indera mengenai penampilan, kelemasan dan kehalusannya. Sedangkan uji fisis mengenai kemuluran kulit kras kambing.

Dari pengamatan secara indera diperoleh, bahwa dalam proses peminyakan menggunakan kuning telur menghasilkan kulit kras kambing dengan permukaan bagian rajah bersih dan halus dari pada bila menggunakan Polarasol SS. Sedang Polarasol SS menghasilkan kulit kras kambing yang lemas dan kemulurannya lebih tinggi bila menggunakan kuning telur. Mengenai hasil uji kemuluran kulit kras dapat dilihat pada tabel 1
Tabel 1. Nilai hasil uji kemuluran kulit kras kambing (\%)

\begin{tabular}{|cccccc|}
\hline & Kuning telur & \multicolumn{3}{c|}{ Polarasol SS } \\
\hline 5,0 & 7,5 & 10,0 & 5,0 & 7,5 & 10,0 \\
\hline 56 & 52 & 54 & 54 & 54 & 52 \\
38 & 46 & 50 & 44 & 44 & 46 \\
40 & 36 & 44 & 44 & 42 & 48 \\
34 & 34 & 44 & 40 & 36 & 42 \\
32 & 36 & 42 & 44 & 36 & 40 \\
34 & 34 & 44 & 38 & 38 & 46 \\
40 & 34 & 44 & 36 & 44 & 46 \\
34 & 40 & 42 & 36 & 38 & 40 \\
38 & 38 & 50 & 36 & 40 & 40 \\
\hline
\end{tabular}

Setelah data pada tabel 1 dianalisis secara statistik dengan CRD pada tabel 2 , ternyata ada beda nyata $(\mathrm{p}<0,01)$ pengaruh penggunaan kuning telur dan Polaraso SS dalam proses peminyakan, terhadap kemuluran kulit kras kambing hasil penelitian.

Tabel 2. Analisa varians data hasil uji kemuluran kulit kras kambing

\begin{tabular}{|lcccc|}
\hline Sumber variasi & df & SS & MS & Fh \\
\hline Perlakuan & 5 & 403,04 & 80,608 & 2,497 \\
Error & 48 & 1549,33 & 32,278 & \\
Total & 53 & & & \\
\hline tabel : 2,41 & & & & \\
\hline
\end{tabular}

$$
3,42
$$

Rata-rata hasil uji kemuluran kulit kras kambing yang berasal dari kulit krom basah dan diminyak dengan kuning telur 5,0\%, 7,5\% dan 10,0\% berturut-turut adalah $38,44 \%, 38,49 \%$ dan $46,0 \%$. Sedangkan rata-rata hasil uji kemuluran kulit kras kambing yang berasal dari kulit krom basah kambing dan diminyak dengan Polarasol SS sebesar 5,0\%, 7,5\% dan 10,0\% berturut-turut adalah 41,33\%, 41,33\% dan 44,44\%. Dengan demikian dapat dikatakan, bahwa makin besar jumlah kuning telur maupun Polarasol SS digunakan dalam proses peminyakan kulit krom basah kambing. Dapat

Vol. XII No. 25 Th. $1997 / 1998$ 
dikatakan pula bahwa hasil uji kemuluran kulit kras kambing yang berasal dari kulit krom basah kambing dan diminyak dengan Polarasol SS, adalah lebih tinggi dari pada hasil uji kemuluran kulit kras kambing yang berasal dari kulit krom basah kambing dan diminyak dengan kuning telur sebesar 10,0\%, hasil uji kemulurannya lebih tinggi dari pada hasil uji kemuluran kulit kras kambing yang berasal dari kuli krom basah kambing dan diminyak dengan Polarasol SS.

Adapun kemungkinan-kemungkinan yang menyebabkan hasil uji kemuluran kulit kras kambing berbeda-beda, meskipun jumlah penggunaannya sama untuk minyak yang berbeda, adalah sebagai berikut :

Selama kulit samak krom masih dalam keadaan basah, maka akan selalu terjadi hidrolisa pada garam krom sulfat basa. Dalam hidrolisa tersebut selalu diikuti terbentuknya asam bebas didalam kulit krom basah.

Asam bebas tersebut akan menghalangi masuknya kuning telur atau Polarasol SS ke dalam kulit krom basah. oleh karena itu asam bebas tersebut harus dihilangkan gar tidak menghalangi masuknya kuning telur atau Polarasol SS ke dalam kulit krom basah sampai bagian dalam dan merata. Asam bebas akan memecah emullsi minyak, dalam hal ini kuning telur atau Polarasol.

Dalam proses netralisasi ada kalanya $\mathrm{pH}$ cairan dan kulit krom basah telah mencapai 4,5-6,5, tetapi kulit krom basah bagian dalam masih mengandung asam bebas sehingga menghalangi masuknya kuning telur atau Polarasol SS sampai bagian dalam kulit krom basah. Tinggi rendahnya kandungan asam bebas di dalam kulit krom basah, mempengaruhi kemampuan kuning telur atau Polarasol SS untuk masuk ke dalamnya. Makin tinggi kandungan asam bebas di dalam kulit krom basah, makin remampuan kuning telur atau Polarasol SS untuk masuk ke dalamnya, sehingga makin rendah pula jumlah fiber kulit yang dilapisi oleh film kuning telur atau Polarasol SS. Dengan demikian apabila kulit kras kambing yang dihasilkan di uji kemulurannya, menghasilkan nilai yang rendah.

Tetapi makin rendah kandungan asam bebas didalam kulit krom basah, makin tinggi kemampuan kuning telur atau Polarasol SS untuk masuk kedalamnya, sehingga makin besar pula jumlah fiber kulit yang dilapisi oleh kuning telur atau Polarasol SS. Dengan demikian apabila kulit kras kambing yang dihasilkan diuji kemulurannya, menghasilkan nilai yang tinggi.

Apabila proses netralisasi dikerjakan dengan baik, dalam hal ini $\mathrm{pH}$ cairan dan kulit krom basah telah mencapai 4,5-6,5, demikian pula kulit krom basah tersebut sudah tidak mengandung asam bebas lagi, maka kuning telur atau Polarasol SS dapat masuk kedalam kulit krom basah bagian fiber. Akibatnya apabila kulit kras kambing yang dihasilkan diuji kemulurannya, menghasilkan nilai yang lebih tinggi.

Jadi perbedaan hasil uji kemuluran kulit kras kambing antara yang berasal
Cari kulit kambing krom basah dan diminyak menggunakan kuning telur dengan yang diminyak menggunakan Polarasol SS, adalah disebabkan karena kandungan asam bebas yang terdapat dalam kulit kambing krom basah. Lain dari pada itu telah disebutkan, bahwa minyak yang digunakan dalam proses peminyakan umumnya inigliserida yang terdapat didalam tumbuh-tumbuhan, hewan dan ikan laut. Kadar inigliserida yang terdapat disetiap tumbuh-tumbuhan, setiap hewan dan setiap ikan laut tidak sama. Demikian pula kadar trigliserida dalam tumbuh-tumbuhan, hewan dan ikan laut tentu tidak sama. Kandungan trigliserida dalam minyak yang digunakan dalam proses peminyakan mempengaruhi kemampuan bagi minyak untuk masuk kedalam penampang kulit. Makin tinggi kandungan trigliserida dalam minyak, makin besar kemampuan minyak untuk masuk kedalam penampang kulit.

\section{KISIMPULAN}

Adapun kesimpulan hasil penelitian adalah sebagai berikut :

1. Ada beda nyata pengaruh penggunaan kuning telur atau Polarasol SS terhadap kemuluran kulit kras kambing yang dihasilkan. Hasil uji kemuluran kulit kras kambing yang berasal dari kulit krom basah kambing dan diminyak dengan Polarasol SS, adalah lebh tinggi dari pada hasil uji kemuluran kulit kras kambing yang berasal dari kulit krom basah kambing dan diminyak dengan kuning telur.

2. Secara umum dapat dikatakan, bahwa makin besar penggunaan kuning telur maupun Polarasol SS, maka makin tinggi hasil uji kemuluran kulit kras kambing.

1. Dalam proses peminyakan menggunakan kuning telur menghasilkan kulit kras kambing dengan permukaan bagian rajah bersih dan halus dari pada bila menggunakan Polarasol SS. Sedang Polarasol SS menghasilkan kulit kras kambing yang lemas dan kemulurannya labih tinggi bila menggunakan kuning telur

\section{SARAN}

Disarankan, untuk mendapatkan kulit kras kambing yang permukaan bagian rajahnya bersih dan halus, pada proses peminyakan kulit krom basah menggunakan kuning telur.

Lain dari pada itu harga telur Rp 2.500,-/kg, sedang harga Polarasol SS Rp. $8000,-/ \mathrm{kg}$

\section{UCAPAN TERIMA KASIH}

Dengan selesainya penelitian "PENGARUH PENGGUNAAN KUNING IELUR DAN POLARASOL SS TERHADAP KEMULURAN KULIT KRAS KAMBING", dan tersusunnya tulisan ini, kam menghaturkan terima kasih kepada

Vol. XII No. 25 Th. $1997 / 1998$ 
Bapak Kepala Balai Besar Penelitian dan Pengembangan Industri Barang Kulit, Karet dan Plastik beserta seluruh Staf atasfasilitas dan bantuannya yang berupa apapun, sehingga penelitian dapat dilaksanakan dan disusun tulisan ini.

\section{DAFTAR PUSTAKA}

1. Indofil Chemical Limited: Leather Finishing Manual. Room and Hass Company, Nelson House, 185 A Besant Road Bombay 400.025.

2. Kirk, R.E. D.F. Othmer : Encyclopedia of Chemical Technology. The Intercience Encyclopedia. Inc New York.

3. O'Flaherty. F. W.T. Roddy and R.M. Lollar: The Chemistry and Technology of Leather. Robert E Krieger Publishing Company Huntington, New York. 1979.

4. Sarkar, K.T. : Theory and Practice of Leather Manufacture. AM Sharif 555, Poonamalle High Road, Madras. 1974.

5. Sharphouse, J.H. Leather Technician's Hand Book. Leather Product Association, 9st. Thomas Street, London Sei.

6. Stadelman, W.J. and O.J. Cotterill. : Egg Science and Technology. The Avi Publishing Company Inc. Wesport, Connecticut. 1973.

7. Steel, R.F. and J.H. Torry. : Principle and Processes of Statistic. Mc Graw Hill Book Company, Inc. New York.

8. Thorstensen, T.C.: Practical Leather Technology. Robert E Krieger Publishing Company, New York. 1976.

9. Wilson, J.A.: Modern Practice in Leather Manufacture. Reinhold Publishing Corporatian, 330 West Forty Second Street New York, AS. 1949. 